\title{
Perforated Horizontal Recharge Pipe Modeling with Non-Linear Regression
}

\author{
Edy Susilo'), Suripin'), and Suharyanto ${ }^{3)}$ \\ 1) Doctoral Student, Diponegoro University, Indonesia. \\ 2) Professor, Civil Engineering Department, Diponegoro University, Indonesia. \\ 3) Lecturer, Civil Engineering Department, Diponegoro University, Indonesia. \\ ${ }^{1}$ ORCID: 0000-0003-1925-6295
}

\begin{abstract}
Population growth and urban development have led to a widespread urbanized land cover leading to a direct increase in surface runoff and a decrease in groundwater infiltration. Various efforts have been carried out in many cities and countries using recharge wells and other structures, to increase groundwater replenishment and decreased flood discharge. This effort succeeded in increasing the groundwater level but was less successful in reducing flood discharge. This study analyzed the use of perforated pipe for groundwater recharge and runoff reduction. The research aims to formulate the infiltration rate into the soil through a perforated horizontal recharge pipe from a full-scale physical model. The research was conducted using 6 pipes of $7.5 \mathrm{~cm}-30 \mathrm{~cm}$ in diameter, 6 types of pipe length between $200 \mathrm{~cm}-700 \mathrm{~cm}, 6$ values of pipe wall porosity $(0.012 ; 0.016 ; 0.020 ; 0.024 ; 0.028$; and 0.032$)$, on texture clay soils with 4 types of soil permeability $\left(3.49 \times 10^{-6}\right.$ $\mathrm{cm} / \mathrm{sec} ; 7.08 \times 10^{-6} \mathrm{~cm} / \mathrm{sec} ; 8.93 \times 10^{-6} \mathrm{~cm} / \mathrm{sec}$; and $1.12 \times 10^{-5}$ $\mathrm{cm} / \mathrm{sec}$ ). The recharge test was carried out under the pipe flow condition (water level above the groundwater level and the pipe is underneath). Observations were used to analyze the influence of 5 variables (water pressure height, pipe diameter, pipe length, wall porosity, and soil permeability) of the perforated recharge pipe by using criteria of correlation coefficient Rsquare, RMSE (Root Mean Square Error), Cp (capability) to achieve the fittest model. The result showed that all variables affect the rate of groundwater filling. Based on a comparison of prediction recharge and observation visually, statistic parameter, and difference index the best-fitted model for perforated horizontal recharge pipe is a non-linear multiple power regression with an R-square 0.8878 . This formula has also been compared with the Torricelli formula (R-square 0.5034) and the Forchheimer formula (R-square 0.7647) with more suitable results. So that research on perforated horizontal recharge pipes can be used more broadly, it is necessary to research recharge pipes on other texture of soil and research recharge pipes with the position of pipes under the groundwater level.
\end{abstract}

Keywords: increase groundwater, recharge, runoff reduction, decrease flood discharge.

\section{INTRODUCTION}

Population growth and urban development have led to a widespread urbanized land cover leading to a direct increase in surface runoff and a decrease in groundwater infiltration [1]. Groundwater exploitation causes environmental problems. One solution is to practice artificial recharge to reduce aquifer depletion [2]. When groundwater abstraction is greater than infiltration or recharge rate it can be recharged using the Bari Doab Pakistan strategy [3]. Additionally, numerous studies have been carried out on the utilization of infiltration wells for flood reduction [4]-[6], infiltration boxes [7], infiltration trenches [8], radial wells [2], and ponds [9]. The use of infiltration wells to reduce flooding is ineffective [10] due to the relatively small recharge [11]. However, it can be effective for groundwater recharge with $2 \mathrm{~m}$ depth or more [12]. This method has been implemented by several countries, including Lahore with a water surface depth of 5 meters which capable of raising the groundwater table by 3.54 feet every rainy season [13]. The excessive groundwater exploitation in India has led to a decline in groundwater levels and seawater intrusion. To overcome these problems, groundwater recharging is carried out using recharge wells [14], thus raising the groundwater table and its availability [2]. The use of retention ponds and water storage structures is not the right choice in urban areas due to limited land space. In urban areas, recharge well is not effective in areas with shallow groundwater table due to its limited capacity to recharge. It, therefore, needs an infiltration structure with a larger capacity to recharge [10].

Perforated Horizontal Recharge Pipe (PHRP) is a perforated pipe installed horizontally to allow more infiltration of runoff into the ground, such that its length dimension is not limited by the groundwater depth. This study aims to determine the recharge capacity using PHRP installed as a function of 1) pipe diameter, 2) length of pipe, 3) wall porosity, 4) soil permeability, and 5) water pressure height. The results of the study can be used as a basis for calculating the PHRP needed to reduce runoff discharge and increase the groundwater recharge in a particular watershed. Additionally, the PHRP installation along a riverbank or drainage channel increases infiltration to the groundwater, recharge the river flows and channels after runoff water subsides, thereby, maintaining the continuity of the flow. PHRP may be an alternative solution for reducing surface runoff and increasing infiltration to groundwater to realize sustainable water management in accordance with the 2015-2030 Sustainable Development Goals (SDGs). The flow in the PHRP may be an open channel flow (partially filled), pipe flow, or in transition. Additionally, the existence of perforated along the pipe length causes the flow is unsteady, and variation on its friction factor along the 
International Journal of Engineering Research and Technology. ISSN 0974-3154, Volume 13, Number 7 (2020), pp. 1724-1734

(C) International Research Publication House. https://dx.doi.org/10.37624/IJERT/13.7.2020.1724-1734

pipe. According to Van Schilfgaarde [15], the hydraulics of perforated pipes buried underground is complicated and requires the use of empirical observations.

This study aims to formulate the infiltration rate into the soil through PHRP below the groundwater level with a statistical approach based on data obtained from a full-scale physical model.

\section{RELATED WORK}

Dimensions of recharge wells, especially nonperforated walls that have been widely implemented to reduce flood discharge
[16] dimensions are limited by the depth of the groundwater level [12]. This equipment is not effective for water infiltration if the bottom of the well is below the groundwater level. PHRP testing with a diameter of $30 \mathrm{~cm}$ long by $2 \mathrm{~m}$ is quite effective to increase infiltration [17]. Placing the PHRP horizontally and perforated walls, long dimensions can be planned to get a large infiltration as needed. The variables and parameters that influence the PRHP infiltration need research.

\section{METHOD}

The study was conducted with a full-scale physical model, with steps as can be seen in Figure 1

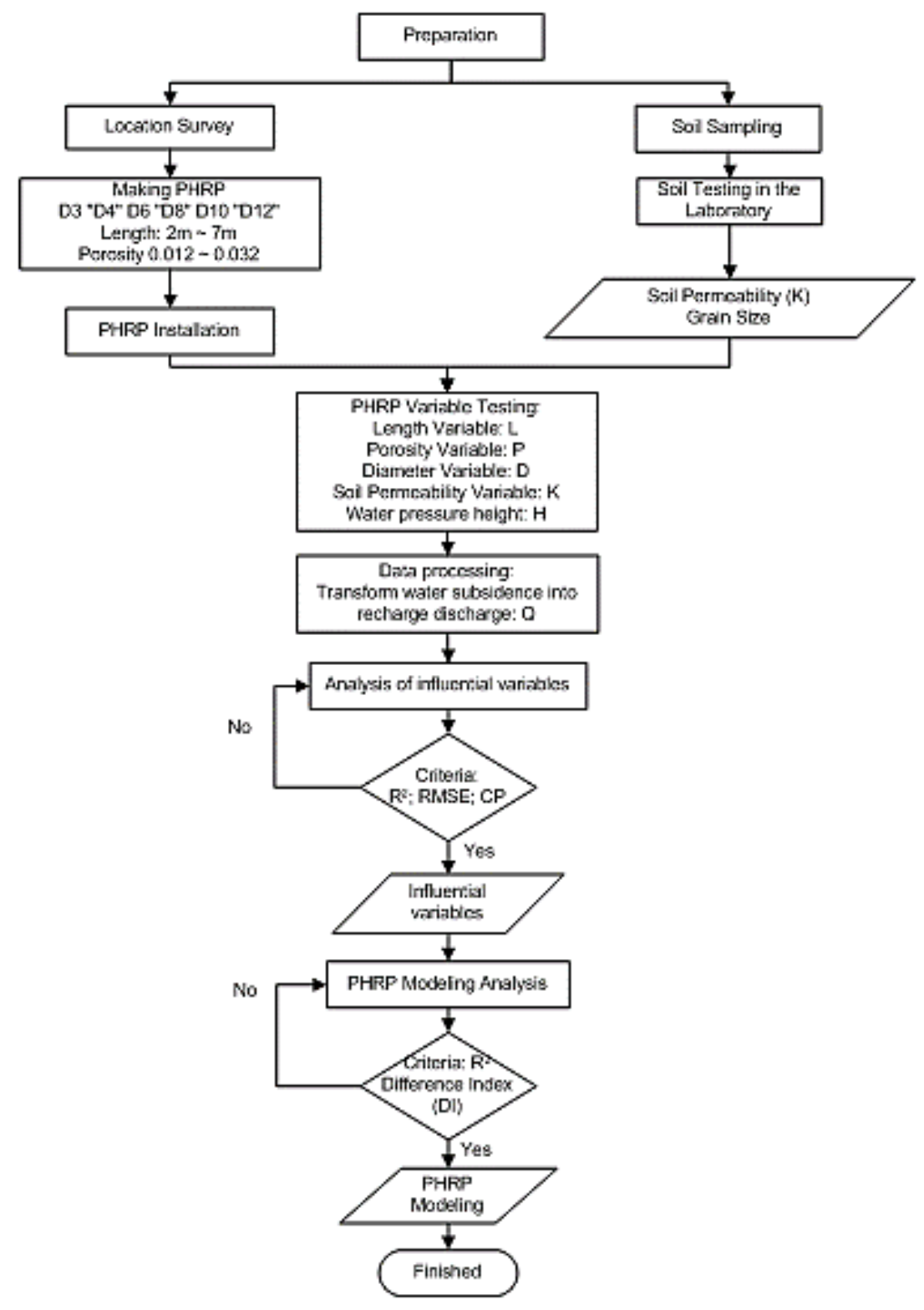

Figure 1: The Stages of research implementation

The study was carried out at different locations to represent various soil permeability $(\mathrm{K})$ and gradation. It uses pipes with diameter D $7.5 \mathrm{~cm}$ (3"), D $10 \mathrm{~cm}$ (4”), D $15 \mathrm{~cm}$ (6"), D $20 \mathrm{~cm}$
(8”), D $25 \mathrm{~cm}(10 ")$, and D 30cm (12"). Along the pipe wall, a perforated is obtained by making several holes with a diameter of $10 \mathrm{~mm}$ to obtain pipe wall porosities of $0.012 ; 0.016 ; 0.020$; 
International Journal of Engineering Research and Technology. ISSN 0974-3154, Volume 13, Number 7 (2020), pp. 1724-1734

(C) International Research Publication House. https://dx.doi.org/10.37624/IJERT/13.7.2020.1724-1734

$0.024 ; 0.028$; and 0.032 respectively. A $100 \mathrm{~cm}$ riser (the vertical part) of the pipe is used to supply water recharge into the pipe. The PHRP is installed in a $100 \mathrm{~cm}$ depth from the ground level as shown in Figure 2.

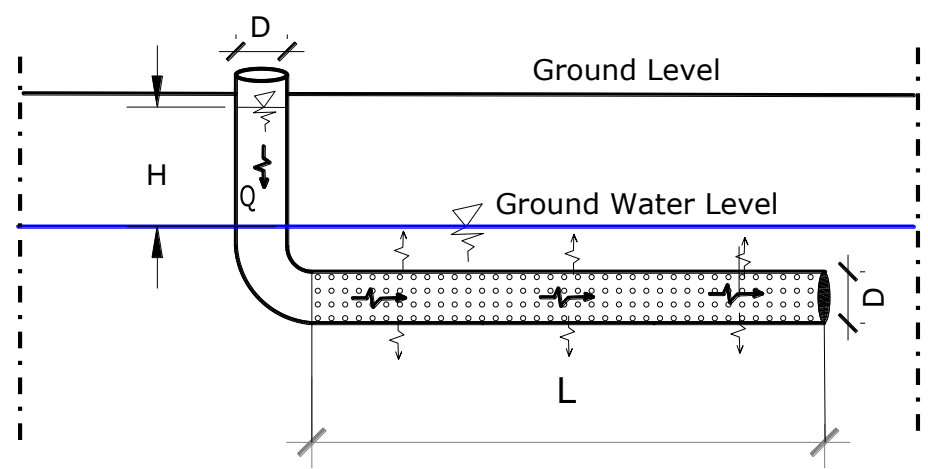

Figure 2:. Installation of perforated recharge pipe in the ground

The end tip of the PHRP buried in the ground is covered with a plug, while the other end is connected to a riser that is open up to ground level. All tests are carried on the condition of the water level at the riser is $\mathrm{H} \mathrm{cm}$ above the groundwater level to guarantee a pipe flow in the horizontal part. Testing is carried out by filling the water into the riser pipe until full. The water level at the riser pipe is then observed for its decrease in time by time. The number of testing and its combination are shown in Table 1.

Table 1. The Number of recharge pipe tests

\begin{tabular}{|c|c|c|c|c|c|c|}
\hline \multirow{2}{*}{\multicolumn{2}{|c|}{$\begin{array}{l}\text { Diameter } \\
\text { D }\end{array}$}} & \multirow{2}{*}{$\begin{array}{l}\text { Pipe Length } \\
\text { L }(\mathrm{cm})\end{array}$} & \multirow{2}{*}{$\begin{array}{c}\text { Porosity } \\
\text { P }\end{array}$} & \multirow{2}{*}{$\begin{array}{l}\text { Permeability } \\
\mathrm{K}(\mathrm{cm} / \mathrm{sec})\end{array}$} & \multicolumn{2}{|c|}{ Number of Tests } \\
\hline & & & & & Combination & Testing \\
\hline \multicolumn{2}{|l|}{ D3 } & L200; L300; L400; L500; L600; L700 & $\mathrm{P} 1 ; \mathrm{P} 2 ; \mathrm{P} 3 ; \mathrm{P} 4 ; \mathrm{P} 5 ; \mathrm{P} 6$ & K7; K11 & $6+12=18$ & 90 \\
\hline \multicolumn{2}{|l|}{ D4 } & L200; L300; L400; L500; L600; L700 & P1; P2; P3; P4; P5; P6 & K7; K9; K11 & $12+6+6=24$ & 120 \\
\hline \multicolumn{2}{|l|}{ D6 } & L200; L300; L400; L500; L600; L700 & P1; P2; P3; P4; P5; P6 & K7; K9; K11 & $6+6+12=24$ & 120 \\
\hline \multicolumn{2}{|l|}{ D8 } & L200; L300; L400; L500; L600; L700 & P1; P2; P3; P4; P5; P6 & K3; K9; K11 & $6+12+6=24$ & 120 \\
\hline \multicolumn{2}{|c|}{ D10 } & L200; L300; L400; L500; L600; L700 & $\mathrm{P} 1 ; \mathrm{P} 2 ; \mathrm{P} 3 ; \mathrm{P} 4 ; \mathrm{P} 5 ; \mathrm{P} 6$ & $\mathrm{~K} 7 ; \mathrm{K} 9 ; \mathrm{K} 11$ & $12+6+6=24$ & 120 \\
\hline \multicolumn{2}{|c|}{ D12 } & L200; L300; L400; L500; L600; L700 & P1; P2; P3; P4; P5; P6 & $\mathrm{K} 4 ; \mathrm{K} 7 ; \mathrm{K} 11$ & $6+6+12=24$ & 120 \\
\hline \multicolumn{3}{|c|}{$\begin{array}{l}\text { Description } \\
\text { 1. Porosity: }\end{array}$} & \multicolumn{2}{|l|}{ Total } & 138 & 690 \\
\hline $\mathrm{P} 1=$ & \multicolumn{2}{|c|}{0.012} & \multicolumn{4}{|l|}{$\mathrm{P} 4=0.024$} \\
\hline $\mathrm{P} 2=$ & \multicolumn{2}{|c|}{0.016} & $\mathrm{P} 5=0.028$ & & & \\
\hline $\mathrm{P} 3=$ & \multicolumn{2}{|c|}{0.020} & $\mathrm{P} 6=0.032$ & & & \\
\hline \multicolumn{7}{|c|}{ 2. Permeability } \\
\hline $\mathrm{K} 3=$ & \multicolumn{2}{|c|}{$3.49 \times 10^{-6} \mathrm{~cm} / \mathrm{sec}$} & & & & \\
\hline $\mathrm{K} 7=$ & \multicolumn{2}{|c|}{$7.08 \times 10^{-6} \mathrm{~cm} / \mathrm{sec}$} & & & & \\
\hline $\mathrm{K} 9=$ & \multicolumn{2}{|c|}{$8.93 \times 10^{-6} \mathrm{~cm} / \mathrm{sec}$} & & & & \\
\hline $\mathrm{K} 11=$ & \multicolumn{2}{|c|}{$1.12 \times 10^{-5} \mathrm{~cm} / \mathrm{sec}$} & & & & \\
\hline
\end{tabular}

The decreasing water level is recorded every 5 seconds using a depth sensor until a constant value of water level in the $100 \mathrm{~cm}$ riser pipe is reached. The data obtained is in the form of water level drop which is processed into infiltration rate out of the 
perforated pipe on the condition of pressurized pipe flow. The data obtained is the recharge rate as a function from a combination of pipe diameter, the porosity of perforated pipe, permeability of the soil, and pipe length.

A statistical software NCSS version 12.0.12 was used to analyze the variables that influence most of the model. The selection of the most appropriate regression model is based on the value of the correlation coefficient (R-square), Root Mean Square Error (RMSE), and its capability (Cp). It also uses a line of perfect agreement plot between observations versus predictions. When the observation and the model fit perfectly then the line is a $45^{\circ}$ slope.

\section{RESULT}

\section{IV.I. Soil investigation}

The recharge water is strongly influenced by the type of soil, with permeability used as an important parameter that influences its recharge [18]. Grain test results and soil permeability in the study area are shown in Table 2 .

Table 2. Property and soil permeability

\begin{tabular}{|c|c|c|c|c|c|c|}
\hline No. & $\begin{array}{c}\text { Density } \\
\mathrm{gr} / \mathrm{cm}^{3}\end{array}$ & $\begin{array}{c}\text { Sand } \\
\%\end{array}$ & $\begin{array}{c}\text { Clay } \\
\%\end{array}$ & $\begin{array}{c}\text { Silt } \\
\%\end{array}$ & $\begin{array}{c}\text { Permeability } \\
\mathrm{cm} / \mathrm{sec}\end{array}$ & $\begin{array}{c}\text { Type of } \\
\text { soil }\end{array}$ \\
\hline 1. & 2.676 & 22.62 & 64.38 & 13.00 & $8.93 \times 10^{-6}$ & Clay \\
\hline 2. & 2.673 & 13.16 & 67.84 & 19.00 & $7.08 \times 10^{-6}$ & Clay \\
\hline 3. & 2.696 & 30.82 & 64.18 & 5.00 & $1.12 \times 10^{-5}$ & Clay \\
\hline 4. & 2.689 & 13.00 & 70.00 & 17.00 & $3.49 \times 10^{-6}$ & Clay \\
\hline
\end{tabular}

The 4 soil samples show that the study area has varying permeability. The soil texture triangle is used by the United States Department of Agriculture (USDA) to classify soil types. The percentages of sand, clay, or silt grains are all included, as shown in Figure 3.

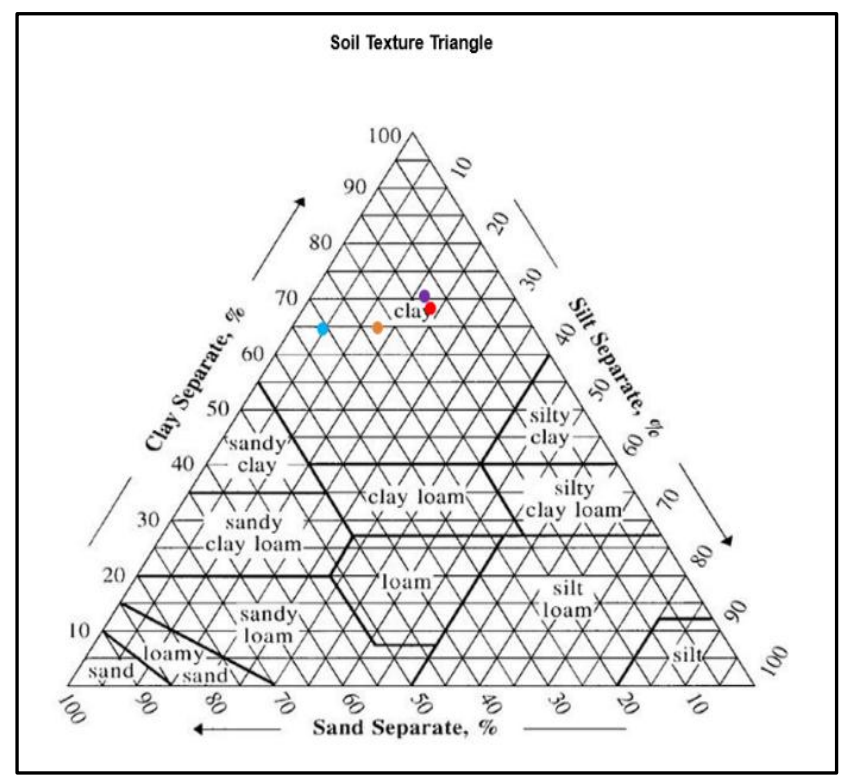

Figure 3: Triangle Soil Texture [19]

\section{IV.II. Variable influential Analysis}

The NCSS 12.0.12 was used to determine the variables influencing the discharge of PHRP recharge, namely water pressure height $(\mathrm{H})$, diameter $(\mathrm{D})$, length $(\mathrm{L})$, soil permeability $(\mathrm{K})$, and porosity of pipe walls $(\mathrm{P})$. The criteria for individual or composite variables are seen from $\mathrm{R}^{2}$ and RMSE [20], [21]. Another criterion for selecting influential variables is Mallow's $\mathrm{Cp}$ statistic, which is formulated on the Equation (1) as follows [21]:

$$
\mathrm{Cp}=\left[\frac{M S E_{p}}{M S E_{k}}\right](\mathrm{n}-\mathrm{p}-1)-\{\mathrm{n}-2(\mathrm{p}+1)\}
$$

Where:

$\mathrm{n} \quad=$ total number of data

$M S E_{p}=$ Mean Square Error with p variable

$M S E_{k}=$ Mean Square Error with k' variable

$\mathrm{p} \quad=$ the number of independent variables forming the model

$\mathrm{k}^{\prime} \quad=$ the total number of independent variables that exist

$\mathrm{Cp}=$ model capabilities

The model is better when The R-square criteria close to 1 . It shows only the similar tendency between model and observed data. The closeness of the model to the observed data is measured using RMSE value. The smaller RMSE indicates the model is better. Cp measures the appropriate number of variables to be used. When the $\mathrm{Cp}$ is close to the number of independent variables $p$ the model is better. When $C p>(p+1)$, it shows that the regression model is over-specified. Meanwhile, $\mathrm{Cp}<(\mathrm{p}+1)$ shows that the regression model is under-specified with some ignored independent variables [21]. Based on the analysis, the best model for several combinations is shown in Table 3 . It shows that the most influential variables consecutively are $\mathrm{H}, \mathrm{D}, \mathrm{K}, \mathrm{L}$, and $\mathrm{P}$.

Table 3. The best model for several combinations of variables

\begin{tabular}{|c|c|c|r|c|}
\hline Size of $\mathrm{p}$ & R-Squared & \multicolumn{1}{c|}{ MSE } & \multicolumn{1}{c|}{ Cp } & Model Variable \\
\hline 1 & 0.31590 & 146.96 & $7,204.80$ & $(\mathrm{H})$ \\
\hline 2 & 0.44993 & 131.79 & $3,003.30$ & $(\mathrm{H})(\mathrm{D})$ \\
\hline 3 & 0.51856 & 123.30 & 852.90 & $(\mathrm{H})(\mathrm{D})(\mathrm{K})$ \\
\hline 4 & 0.54566 & 119.78 & 4.94 & $(\mathrm{H})(\mathrm{D})(\mathrm{K})(\mathrm{L})$ \\
\hline 5 & 0.54569 & 119.78 & 6.00 & $(\mathrm{H})(\mathrm{D})(\mathrm{K})(\mathrm{L})(\mathrm{P})$ \\
\hline
\end{tabular}

It can be seen that the use of 1 additional variable from 4 variables led to the addition of very small $R^{2}(0.00003)$, producing similar RMSE, but gives better $\mathrm{Cp}$. It indicates that the number of variables can be 4 or 5 . The influence of the number of variables used in the values of R-Squared, RMSE, and $\mathrm{Cp}$ is shown in Figure 4. 
International Journal of Engineering Research and Technology. ISSN 0974-3154, Volume 13, Number 7 (2020), pp. 1724-1734

(C) International Research Publication House. https://dx.doi.org/10.37624/IJERT/13.7.2020.1724-1734
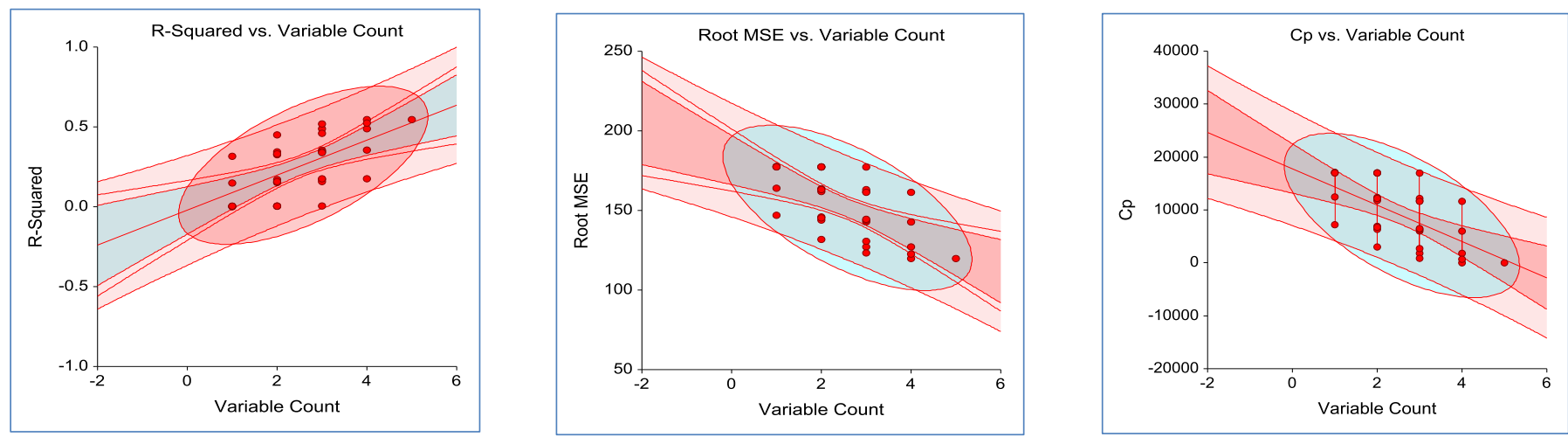

Fig. 4. R-Square, RMSE, and Cp values for the number of variables used.

Figure 4 shows the criteria of R-Square, RMSE, and Cp the best sequence combination of two variables are H-D, H-L, H-K, and H-P. Meanwhile, the best sequence combination of three variables is H-D-K, H-D-L, H-D-P, and H-L-K. The best sequence combination of 4 variables is H-D-K-L, H-D-K-P. For all variables used in the model, it has an H-D-K-L-P combination such as shown in Table 3. Furthermore, modeling with regression will use 5 variables.
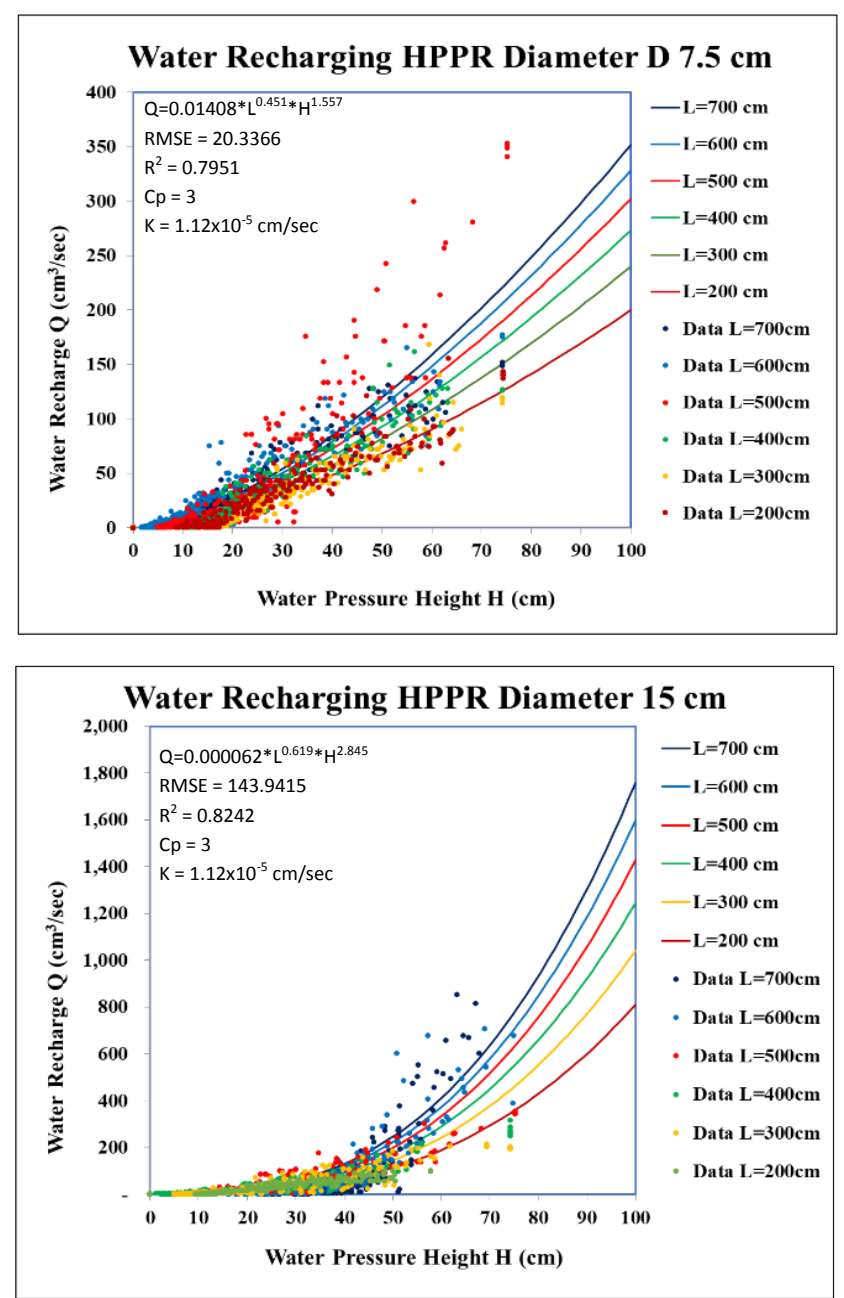

\section{IV.III. Length Variable}

To analyze the influence of the length variable, it assumed that all other variables are fixed. The recharge capacity is dependent variable as a function of pipe length $\mathrm{L}$ and pressure height $\mathrm{H}$. The data analyzed is using all pipe diameters with pipe porosity 0.016 and the different soil permeability for each diameter. The experiment results show the perforated pipe recharge capacity as a function of $\mathrm{L}$ and $\mathrm{H}$ such as shown in Figure 5.
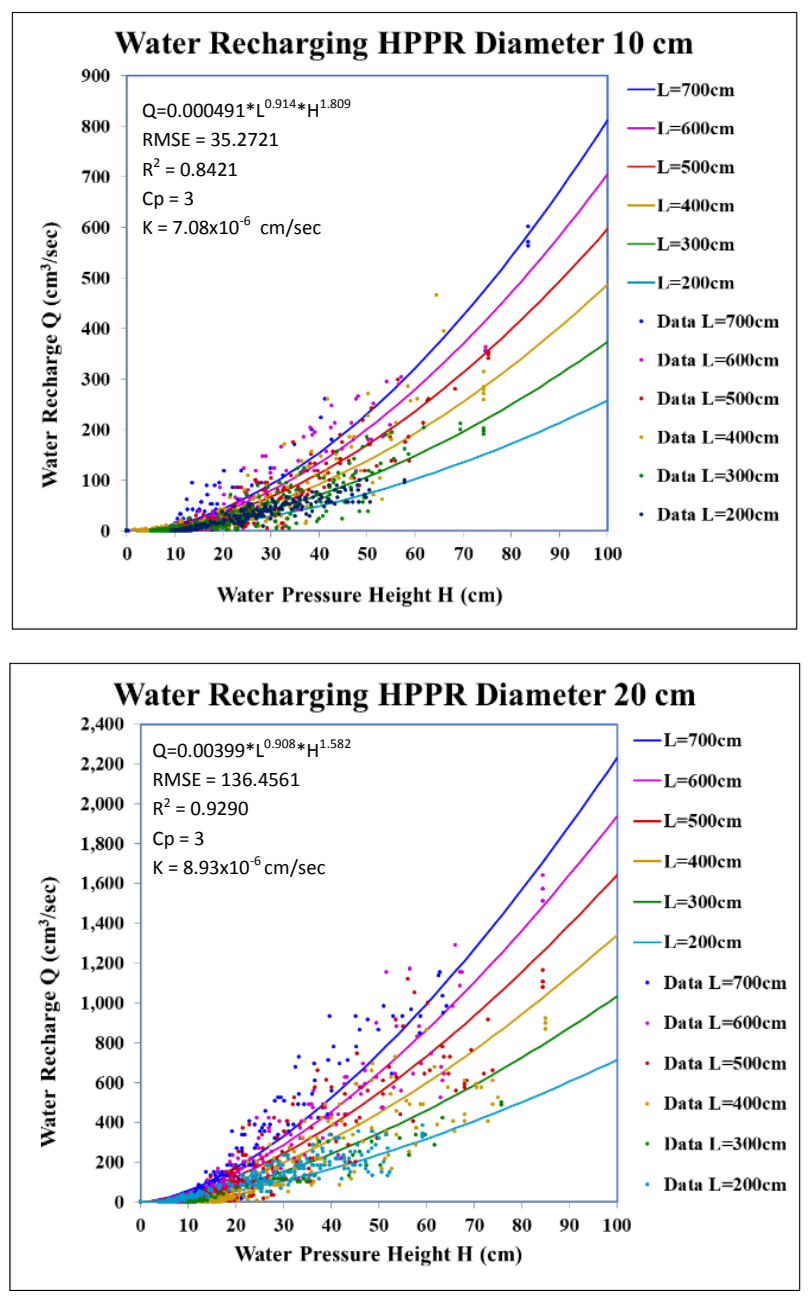

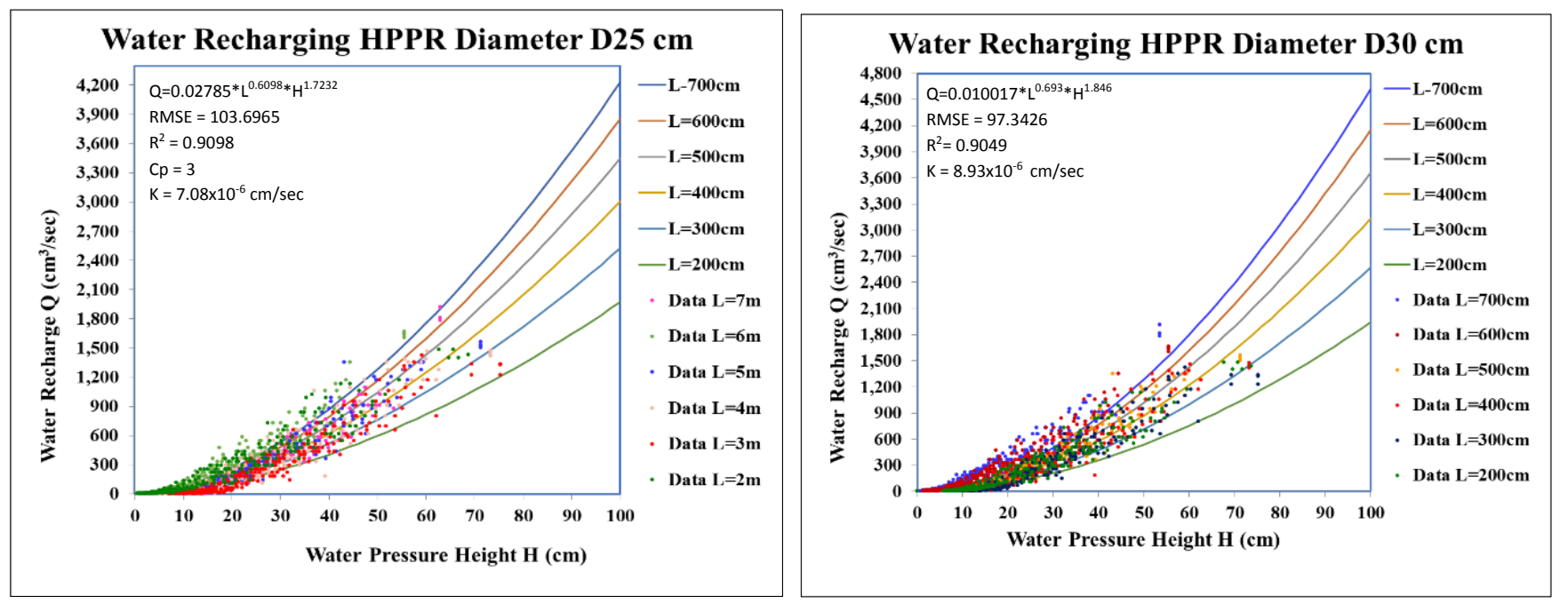

Fig. 5. Recharge capacity $Q$ as a function from pipe length $L$.

The appropriate model form is non-linear power multiple regression with the general equation (2):

$$
\mathrm{Q}=\mathrm{A} * \mathrm{~L}^{\mathrm{B} *} \mathrm{H}^{\mathrm{C}}
$$

where:

$$
\begin{aligned}
& \mathrm{Q}=\text { recharge water }\left(\mathrm{cm}^{3} / \mathrm{sec}\right) \\
& \mathrm{L}=\text { length of pipe }(\mathrm{cm}) \\
& \mathrm{H}=\text { water pressure height }(\mathrm{cm}) \\
& \mathrm{A}=\text { a constant } \\
& \mathrm{B}=\text { power for the length variable } \\
& \mathrm{C}=\text { power for water pressure height variable }
\end{aligned}
$$

From Figure 5 the six diameters of the pipe used to observe length parameters, the power of regression obtained from the variable $L$ is between 0.619 to 0.914 with $R^{2}$ between 0.7951 to 0.9290 due to a decrease in flow and major energy loss.

In pipe flow, there is energy loss along the pipe length. The energy loss due to friction along the pipe wall can be expressed by the Darcy-Weisbach equation:

$$
H_{f}=f \frac{L}{D} \frac{V^{2}}{2 g}
$$

$\mathrm{f} \quad=$ coefficient of friction

$\mathrm{L} \quad=$ pipe length $(\mathrm{cm})$

$\mathrm{D}=$ inner pipe diameter $(\mathrm{cm})$

$\mathrm{g}=$ acceleration of gravity $\left(\mathrm{cm} / \mathrm{sec}^{2}\right)$

$\mathrm{H}$ = water pressure height $(\mathrm{cm})$

$\mathrm{H}_{\mathrm{f}}=$ loss of energy $(\mathrm{cm})$
The infiltration rate of PRPH is not linear to the length of the pipe due to a decrease in water pressure height, and energy loss due to friction in the pipe wall shown in equation (3) DarcyWeisbach, where the energy loss is proportional to the length of the pipe and the square of the velocity, and inversely proportional to the diameter of the pipe. Thus the reduced water pressure height along the pipe is also not linear. In this case, the recharge of water from the pipe into the ground and velocity is smaller, so the energy loss is also smaller. The loss of energy in the flow of water in a perforated pipe depends not only on the length of the pipe but also is influenced by the diameter. Thus the recharge of water in perforated horizontal pipes is influenced by the length and diameter. The PRHP installed buried underground experiences more complex hydraulic conditions.

\section{IV.IV. Pipe Porosity Variable}

The influence of the porosity of the pipe wall is obtained by setting other variables fixed. In this analysis, it uses a pipe length of 2 meters, with the soil permeability different for each diameter.

The diameter pipe is $7.5 \mathrm{~cm}, 10 \mathrm{~cm}, 15 \mathrm{~cm}, 20 \mathrm{~cm}, 25 \mathrm{~cm}$, and $30 \mathrm{~cm}$ with a porosity of $0.012(\mathrm{P} 1), 0.016(\mathrm{P} 2), 0.020(\mathrm{P} 3)$, 0.024 (P4), 0.028 (P5), and 0.032 (P6), respectively, using a water height and pipe length of 2 meters as shown in Figure 5. 

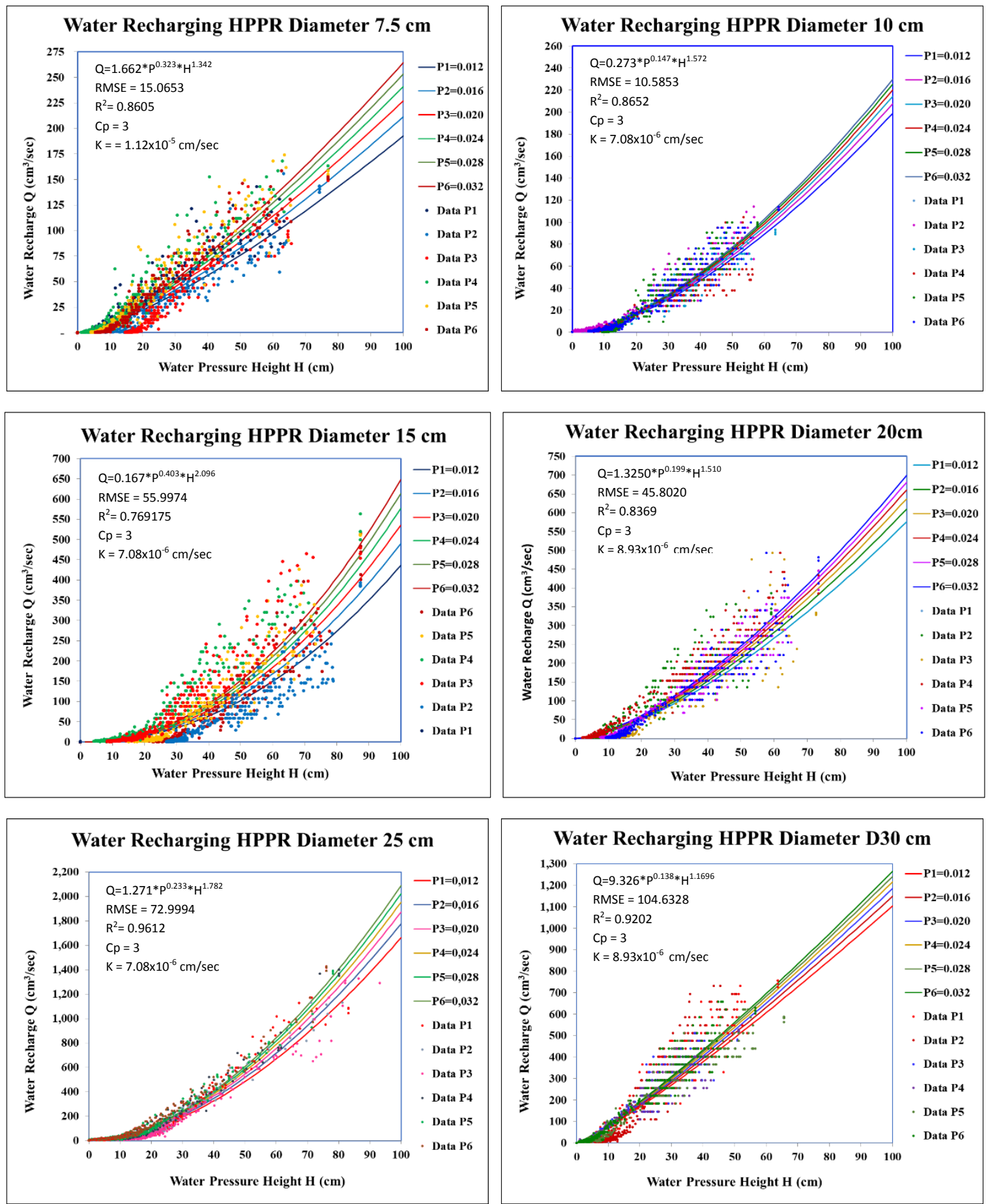

Figure 6: Perforated recharge pipe with wall porosity variable

The appropriate model form for porosity variables is non-linear power multiple regression model with the general equation (4):

$$
\mathrm{Q}=\mathrm{A} * \mathrm{P}^{\mathrm{B}} * \mathrm{H}^{\mathrm{C}}
$$

where:

$$
\begin{aligned}
& \mathrm{Q}=\text { recharge water }\left(\mathrm{cm}^{3} / \mathrm{sec}\right) \\
& \mathrm{P}=\text { porosity of pipe wall } \\
& \mathrm{H}=\text { water pressure height }(\mathrm{cm})
\end{aligned}
$$
$\mathrm{A}=\mathrm{a}$ constant
$\mathrm{B}=$ power constant to porosity variable
$\mathrm{C}$ = power constant to water pressure height variable

From figure 6, the six diameters of the pipe used to observe the parameters of the porosity of the pipe wall, the power of regression obtained from the variable $\mathrm{P}$ is between 0.1098 to 0.323 with $\mathrm{R}^{2}$ between 0.8369 to 0.9612 . The effect of porosity variable is smaller than the length variable. The difference in 
the porosity of the pipe wall does not significantly affect PHRP recharger, indicating the porosity of the pipe wall is more porous than the soil media. Permeability of clay soils at the research site is $3.49 \times 10^{-6} \mathrm{~cm} / \mathrm{sec}$ to $1.12 \times 10^{-5} \mathrm{~cm} / \mathrm{sec}$ no more porous compared to the porosity of the pipe wall of 0.012 to 0.032. This shows the influence of the porosity variable is not too large.

In the condition of full water in the pipe, water recharge through perforated pipes is influenced by porous media and porosity of the pipe. If the porosity of the media outside the pipe is higher than the porosity of the pipe, then the recharge of water into the soil is determined by the porosity of the pipe. Conversely, if the porosity of the pipe is greater than the media, then water recharge is determined by the media [22]. In this case, the influence of the porosity of the pipeline is greater than the porosity of the soil media so that the influence of the porosity of the pipe wall is small. Water recharger retained by soil media.

Pipe diameter and soil permeability variables are analyzed by combining all influential variables.

\section{IV.V. Combined Variables}

The combined dependent variables analyzed in this regression are the pipe length $(\mathrm{L})$, porosity of pipe wall $(\mathrm{P})$, pipe diameter (D), soil permeability $(\mathrm{K})$, and water pressure height $(\mathrm{H})$. The recharge water capacity $(\mathrm{Q})$ is the independent variable.

The discharge which flows through small holes in pipe flow according to the famous Torricelli's formula is expressed by the equation [23]:

$$
Q=C_{d} . a \sqrt{2 \cdot g \cdot H}
$$

where:

$$
\begin{aligned}
\mathrm{Cd} & =\text { discharge coefficient } \\
\mathrm{A} & =\text { area of opening hole }\left(\mathrm{m}^{2}\right) \\
\mathrm{G} & =\text { acceleration of gravity }\left(\mathrm{m} / \mathrm{sec}^{2}\right) \\
\mathrm{H} & =\text { water pressure height }(\mathrm{m}) \\
\mathrm{Q} & =\text { discharge flow }\left(\mathrm{m}^{3} / \mathrm{sec}\right)
\end{aligned}
$$

Sriyono has used this basic equation (5) to formulate a flowrate from the soil media into a porous pipe [22]. The use of equation (5) by adding a variable area opening hole (a) and the coefficient of discharge $(\mathrm{Cd})$ is a function of the variables $\mathrm{K}, \mathrm{D}$ and $\mathrm{L}$. The $\mathrm{P}$ variable is removed because it is represented by the variable a. The equation obtained is:

$$
Q=210.16 \mathrm{~K}^{1.077} * \mathrm{D}^{0.613} * \mathrm{~L}^{-0.166} * \mathrm{a} \sqrt{2 \cdot \mathrm{g} \cdot \mathrm{H}}
$$

then,

$$
\mathrm{C}_{\mathrm{d}}=210.16 \mathrm{~K}^{1.077} * \mathrm{D}^{0.613} * \mathrm{~L}^{-0.166}
$$

The correlation coefficient of the regression equation (6) is 0.5034 , indicating that the correlation of variables and parameters with water recharging is not good. The parameter $\mathrm{L}$ is negative because the area of the opening hole (a) is more influential.

The recharging using a vertical tube inserted into the ground is as big as [24]:

$$
\begin{aligned}
\mathrm{Q} & =\mathrm{F} \cdot \mathrm{K} \cdot \mathrm{H} \\
\mathrm{F} & =\text { geometry factor }(\mathrm{cm}) \\
\mathrm{K} & =\text { soil permeability coefficient }(\mathrm{cm} / \mathrm{sec}) \\
\mathrm{H} & =\text { water pressure height }(\mathrm{cm}) \\
\mathrm{Q} & =\text { flow recharge }(\mathrm{cm} 3 / \mathrm{sec})
\end{aligned}
$$

Equation (8) by Sunjoto is used for elaborating the recharge formula that absorbs through the recharge well. The use of equation (8) with the geometry factor $(F)$ is a function of the variables $\mathrm{P}, \mathrm{D}$, and $\mathrm{L}$. The equation obtained is (9):

$$
\mathrm{Q}=120.96 \mathrm{P}^{0.187} * \mathrm{D}^{1.697} * \mathrm{~L}^{0.745} * \mathrm{~K} * \mathrm{H}
$$

According to equation (8), then

$$
\mathrm{F}=120.96 \mathrm{P}^{0.187} * \mathrm{D}^{1.697} \mathrm{~L}^{0.745}
$$

The correlation coefficient of the regression equation (9) is 0.7647 , indicating that the correlation between the variables and the parameters is not good. Equation (9) is better than the regression equation (6)

Non-linear regression models for the independent variables $\mathrm{K}$, $\mathrm{P}, \mathrm{D}, \mathrm{L}$, and $\mathrm{H}$ with all these parameters are shown by equation (11):

$$
\mathrm{Q}=110.99 \mathrm{~K}^{1.2896} * \mathrm{P}^{0.121} * \mathrm{D}^{2.038} * \mathrm{~L}^{0.718} * \mathrm{H}^{1.626}
$$

The correlation coefficient of the regression equation (11) is 0.8878

Equation (11) shows that the PHRP influenced by water pressure height, pipe length, diameter, and soil permeability, while the influence of the porosity of the pipe wall $(\mathrm{P})$ on the recharge is small. The length parameter is 0.718 , while the porosity is 0.121 . The length and porosity parameters, both meet the results of the analysis of a single variable as can be seen in Figure 5 and Figure 6. Judging from the analysis of influetial variables, equation (11) is significant.

\section{DISCUSSION}

\section{V.I. Double Plotting observation of predictions}

A comparison of prediction recharge and observation based on equation (6), (9), and (11) is plotted in Figure 7. 
International Journal of Engineering Research and Technology. ISSN 0974-3154, Volume 13, Number 7 (2020), pp. 1724-1734

(C) International Research Publication House. https://dx.doi.org/10.37624/IJERT/13.7.2020.1724-1734

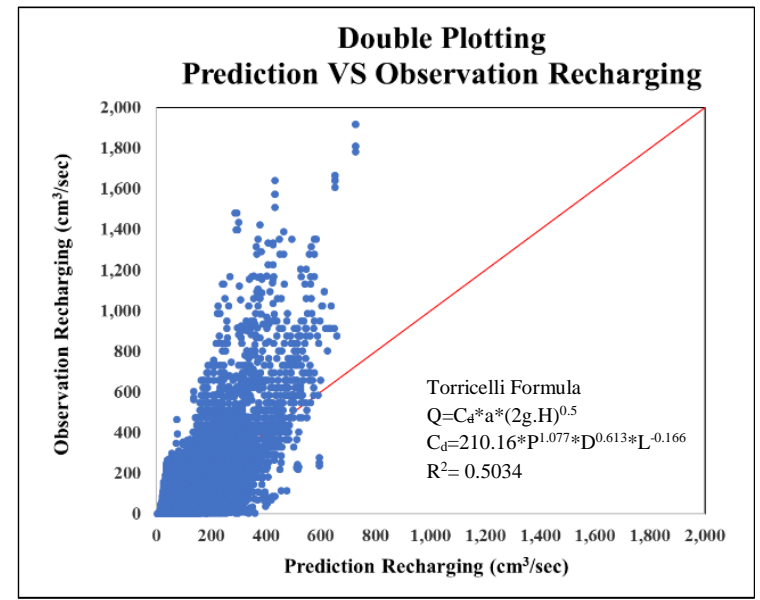

Fig. 7a. Double plotting Torricelli Formula

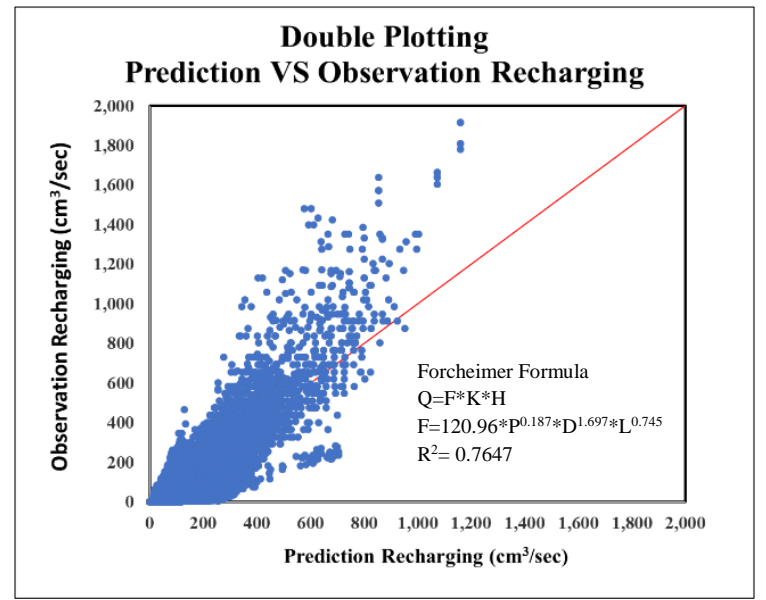

Fig. 7b. Double plotting Forcheimer Formula

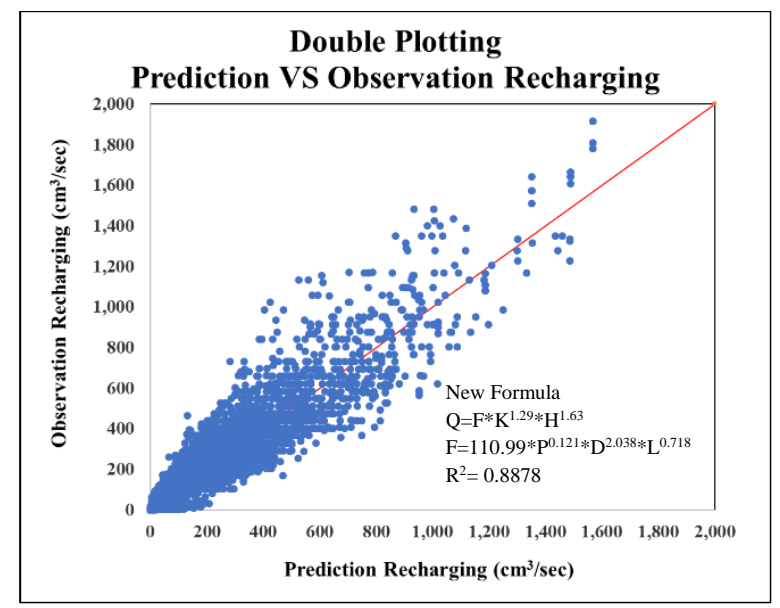

Fig. 7c. Double plotting NewFormula

Fig. 7. Double plotting of prediction and observation recharge

By comparing 3 equations (6), (9), and (11) based on the highest R-square, and the scatter plot (Fig. 7) equation (11) is the fittest model for PHRP.

\section{V.II. Difference Index}

The difference index (DI) is defined as the ratio between the deviation of the predicted and observed values expressed by equation (12):

$$
D I=\frac{\left|Q_{o}-Q_{p}\right|}{Q_{o}} \times 100 \%
$$

The difference index is a measure used to determine the possibility of accepting or rejecting a model, with the following limitations:

$\begin{array}{lll}\text { Difference index: } & \text { DI }<10 \% & \rightarrow \text { good } \\ \text { Difference index: } & 10 \%<\text { DI }<30 \% & \rightarrow \text { acceptable } \\ \text { Difference index: } & \text { DI }>30 \% & \rightarrow \text { bad }\end{array}$

From 14,255 observational data on the relationship between water pressures height and water recharge, DI for the Torricelli Formula, Forchheimer Formula, and New Formula for a specific water pressure height can be seen in Table 4 .

where:

Qo = observed of recharge (\%)

$\mathrm{Qp} \quad=\quad$ predicted of recharge $(\%)$

DI $=$ difference index $(\%)$ 
International Journal of Engineering Research and Technology. ISSN 0974-3154, Volume 13, Number 7 (2020), pp. 1724-1734

(C) International Research Publication House. https://dx.doi.org/10.37624/IJERT/13.7.2020.1724-1734

Table 4. Difference index for some water pressures height with the Torricelli Formula, the Forchheimer Formula, and the New Formula

\begin{tabular}{|c|c|c|c|c|}
\hline \multirow{2}{*}{ No. } & \multirow{2}{*}{ Water Height } & \multicolumn{3}{|c|}{ Difference Index (\%) } \\
\cline { 3 - 5 } & & Torricelli Formula & Forchheimer Formula & New Formula \\
\hline 1. & $0 \mathrm{~cm}-100 \mathrm{~cm}$ & $1318.18 \%(\mathrm{bad})$ & $760.54 \%(\mathrm{bad})$ & $266.42 \%(\mathrm{bad})$ \\
\hline 2. & $10 \mathrm{~cm}-100 \mathrm{~cm}$ & $794.63 \%(\mathrm{bad})$ & $579.06 \%(\mathrm{bad})$ & $252.01 \%(\mathrm{bad})$ \\
\hline 3. & $20 \mathrm{~cm}-100 \mathrm{~cm}$ & $107.53 \%(\mathrm{bad})$ & $88.61 \%(\mathrm{bad})$ & $53.85 \%(\mathrm{bad})$ \\
\hline 4. & $30 \mathrm{~cm}-100 \mathrm{~cm}$ & $43.94 \%(\mathrm{bad})$ & $38.77 \%(\mathrm{bad})$ & $26.85 \%(\mathrm{acceptable})$ \\
\hline 5. & $40 \mathrm{~cm}-100 \mathrm{~cm}$ & $40.64 \%(\mathrm{bad})$ & $34.77 \%(\mathrm{bad})$ & $24.05 \%(\mathrm{acceptable})$ \\
\hline 6. & $50 \mathrm{~cm}-100 \mathrm{~cm}$ & $41.85 \%(\mathrm{bad})$ & $35.97 \%(\mathrm{bad})$ & $23.31 \%(\mathrm{acceptable})$ \\
\hline 7. & $60 \mathrm{~cm}-100 \mathrm{~cm}$ & $44.82 \%(\mathrm{bad})$ & $41.20 \%(\mathrm{bad})$ & $21.09 \%(\mathrm{acceptable})$ \\
\hline 8. & $70 \mathrm{~cm}-100 \mathrm{~cm}$ & $47.33 \%(\mathrm{bad})$ & $46.73 \%(\mathrm{bad})$ & $18.28 \%(\mathrm{acceptable})$ \\
\hline 9. & $80 \mathrm{~cm}-100 \mathrm{~cm}$ & $41.51 \%(\mathrm{bad})$ & $35.22 \%(\mathrm{bad})$ & $11.63 \%(\mathrm{acceptable})$ \\
\hline
\end{tabular}

Based on the difference index for some water pressure height using the Torricelli formula and the Forchheimer formula, both are not acceptable. As for the new formula, for water pressure higher than $30 \mathrm{~cm}$, DI is still acceptable. Thus based on Rsquare and DI then equation (11) of the new formula is the fittest model for PHRP.

\section{CONCLUSIONS}

The use of PHRP for groundwater filling and the significant reduction of flood discharge is concluded as follows:

1. The best model for PRHP is a regression equation with a correlation coefficient of 0.8878 obtained as follows:

$\mathrm{Q}=110.99 \mathrm{~K}^{1.2896} * \mathrm{P}^{0.121} * \mathrm{D}^{2.038} * \mathrm{~L}^{0.718} * \mathrm{H}^{1.626}$

2. The variables that greatly affect the recharge of perforated recharge pipe successive are pipe length, diameter, porosity, and soil permeability.

3. Research on perforated horizontal pipes in the condition of groundwater under the pipe needs to be carried out for the development of this research.

4. This research was conducted on clay texture. To use this research extensively, it is recommended horizontal pipe infiltration research on other types of soils be recommended

\section{ACKNOWLEDGMENT}

The authors are thankfully acknowledged the Diponegoro University Alumni Foundation for funding this research. Also grateful to Soil Mechanics Laboratory Faculty of Engineering the Diponegoro University for providing the necessary support for soil investigations.

\section{REFERENCES}

[1] M. Minnig, C. Moeck, D. Radny, and M. Schirmer, 2018, "Impact of urbanization on groundwater recharge rates in Dübendorf, Switzerland," J. Hydrol., vol. 563, pp. 1135-1146.

[2] J. A. Albaladejo-García and D. Prats-Rico, 2017, "Artificial groundwater recharge. review of the current knowledge of the technique," Rev. la Soc. Geol. Espana, vol. 30, no. 1, pp. 85-96.

[3] M. Basharat and M. Basharat, 2019, "Developing SukhBeas as a potential recharge site during wet years for Bari Doab," Appl. Water Sci., vol. 9, no. 7.

[4] R. Elsa, B. Sujatmoko, and M. Fauzi, 2018, "Efektifitas Pemanfaatan Sumur Resapan Untuk Mereduksi Limpasan Permukaan,” Jom FTEKNIK, vol. 5, no. 2, pp. $1-7$.

[5] P. Patel, M. Desai, and J. Desai, 2011, "Geotechnical Parameters Impact on Artificial Ground Water Recharging Technique for Urban Centers," J. Water Resour. Prot., vol. 03, no. 05, pp. 275-282.

[6] J. Guttman, I. Negev, and G. Rubin, 2017, "Design and testing of recharge wells in a coastal aquifer: Summary of field scale pilot tests," Water (Switzerland), vol. 9, no. 1.

[7] S. Adinda and A. Ikhsan, 2014, "Pengaruh Pemodelan Kotak Resapan Buatan di Saluran Drainase terhadap Debit Limpasan," J. Ilm. Semesta Tek., vol. 17, no. 1, pp. 61-67.

[8] S. Sunjoto, 2008, "The Recharge Trench As a Sustainable Supply System,” J. Environ. Hydrol., vol. 16, no. January, pp. 1-11. 
[9] S. Packialakshmi, S. Balaji, and T. Kumaresan, 2015, "Inducing Recharge of Groundwater by Treated Waste Water - A Pilot Study in Southern Chennai Metropolitan Area,” Indian J. Sci. Technol., vol. 8, no. 11.

[10] E. Susilo, Suripin, and Suharyanto, 2018, "Field performance of shallow recharge well," MATEC Web Conf., vol. 195, p. 05006.

[11] E. Susilo, B. Sudarmanto, and B. Purnijanto, 2017, "Kajian Empiris Sumur Resapan pada Tanah Silt," Teknika, vol. 12, no. 2, pp. 37-44.

[12] SNI 8456, 2017, "Standar Nasional Indonesia: Sumur dan parit resapan air hujan,".

[13] F. Hussain, R. Hussain, R. S. Wu, and T. Abbas, 2019, "Rainwater harvesting potential and utilization for artificial recharge of groundwater using recharge wells," Processes, vol. 7, no. 9.

[14] A. K. Bhattacharya, 2010, "Artificial Ground Water Recharge With a Special Reference To India," Int. J. Res. Rev. Appl. Sci. - IJRRAS, vol. 4, no. August, pp. 214-221.

[15] V. Schilfgaarde, 2016, "Drainage for Agriculture, Agronomy Monograph," pp. i-xxiv.

[16] Sunjoto, 1989, "Teknik Konservasi Air pada Kawasan Pemukiman,” Media Teknik, vol. 2. pp. 76-82.

[17] E. Susilo and D. S. S. Budiningrum, 2019, "Kinerja Pipa Resapan sebagai Pendukung Konservasi Air," Teknika, vol. 14 , no. 2 , p. 65 .

[18] A. Rachmawati, Suhardjono, U. Andawayanti, and P. Tri Juwono, 2020, "In situ permeability and shape factor of flat-base recharge wells using variations of porous walls," IOP Conf. Ser. Earth Environ. Sci., vol. 437, no. 1, p. 012031.

[19] S. J. Thien, 1979, "Determining soil texture by feel," J. Agric. Educ., vol. 8, pp. 54-55.

[20] H. Pham, 2019, "A new criterion for model selection," Mathematics, vol. 7, no. 12, pp. 1-12.

[21] Jerry L. Hintze, 2007, "User's Guide III. Regression and Curve Fitting".

[22] E. Sriyono, 2013, "Kajian Hitungan Debit Aliran Melalui Pipa Berpori Terhadap Kapasitas: Media Porous, Pori Pipa, dan Orifice," J. Tek., vol. 3, no. 1.

[23] T. Yu, X. Zhang, I. E. Lima Neto, T. Zhang, Y. Shao, and M. Ye, 2019, "Impact of Orifice-to-Pipe Diameter Ratio on Leakage Flow: An Experimental Study," Water, vol. 11, no. 10, p. 2189.

[24] P. Forchheimer, 1930, "Hydraulik". Leipzig, Berlin, B.G. Teubner. 